\title{
MOTHER-TONGUE EDUCATION, LINGUISTIC VARIATION AND LANGUAGE PROCESSING
}

\author{
Mercedes Marcilese ${ }^{1^{*}}$ \\ Cristina Name ${ }^{1^{* *}}$ \\ Marina Augusto ${ }^{2 * * x}$ \\ Daniele Molina ${ }^{1 * * * x}$ \\ Raiane Armando ${ }^{2 * * * * *}$ \\ ${ }^{1}$ NEALP/Universidade Federal de Juiz de Fora, Juiz de Fora, MG, Brasil \\ ${ }^{2}$ Universidade do Estado do Rio de Janeiro, Rio de Janeiro, RJ, Brasil
}

\begin{abstract}
This paper explores an intersection between three main topics: (i) sociolinguistic variation, (ii) variation acquisition and processing according to a psycholinguistic approach and (iii) mother-tongue teaching/learning when the two previous factors are taken into account. Nonstandard linguistic varieties coexist in society with a standardized variety that could be defined as the 'language of education. The distance between standard forms and the variety acquired by children at home is quite variable and could have an impact on how and when the formal register becomes (or not) part of the range of linguistic speaker's options. In order to address these issues, we provide experimental results regarding the comprehension and production of two linguistic aspects that show a high variation in Brazilian Portuguese- verbal agreement and anaphoric forms in direct object position - as a function of formal education exposure; we also articulate these results with the concepts of core grammar and marked periphery (Kato, 2005) for a more theoretical discussion.

Key-words: Sociolinguistic Variation; Language Acquisition, Language Processing; Mother-tongue Education; Core Grammar.
\end{abstract}

\footnotetext{
" PhD in Language Studies (PUCRIO). Adjunct Professor at the Federal University of Juiz de Fora. Email: mercedes.marcilese@uff.edu.br ORCID https://orcid.org/0000-0002-9058-8367

${ }^{* *} \mathrm{PhD}$ in Language Studies (PUCRIO). Associate Professor at the Federal University of Juiz de Fora and fellow of the Brazilian National Council for Scientific and Technological Development (CNPq). Email: cristina.name@ uff.edu.br ORCID: https://orcid.org/0000-0001-5625-9503

${ }^{* * *} \mathrm{PhD}$ in Linguistics (UNICAMP). Adjunct Professor at the State University of Rio de Janeiro. Email: marinaaug@uerj.br. ORCID: orcid.org/0000-0002-9022-394X

${ }^{* * *} \mathrm{PhD}$ in Linguistics from the Federal University of Juiz de Fora. Email: daniele.molina@uff.edu.br. ORCID: https://orcid.org/0000-0002-8555-3039

${ }^{* * * * *} \mathrm{PhD}$ candidate at the State University of Rio de Janeiro. Email: raianearmando@hotmail.com. ORCID: https://orcid.org/0000-0003-0699-8636
} 


\section{Introduction}

\section{'A shprakh iz a dialekt mit an armey un flot' [A language is a dialect with an army and navy] (quotation attributed to Max Weinreich)}

In most speech communities, non standard language varieties coexist with a standardized variety that could be considered the 'language of education'. To which extent the standard variety is, in fact, an idealized set of abstract norms about language or a "true" dialect with a written form that is employed by educated members of a given society remains as an open question in the context of the sociolinguistics debate (Cheshire, 2005).In any case, it could be said that the standard variety conveyed in educational practices represents a contemporary version of the 'army and navy' mentioned in Weinreich quotation above. An important issue related to this fact is that, depending on the specific social group, while for some children the standard variety is quite close to that they acquired at home, for many others there may be a much greater distance between what is spontaneously acquired in their everyday life and the variety taught at school. The differences between standard and non-standard varieties can include different levels of grammar, including phonology, morphosyntax and vocabulary, among others. Several research questions arise from the picture previously outlined: Are standard and non-standard varieties processed in a similar way by the speakers in terms of perception and comprehension? To what extent do the differences between linguistic varieties have an impact on the mother-tongue teachinglearning process? How does the acquisition/learning process of the standard variety occur in the school context? How can the linguistic knowledge (i.e. the grammar) of a literate or educated speaker be described, and how does she/he develop this knowledge (Kato, 2005)?

In the framework of generative theory (Chomsky, 1986), the acquisition of a natural grammar is the result of a biological endowment and exposition to a particular language. Every child will pick up a vocabulary and fix values for particular features of the language, leading her/him to grow a grammar during verbal spontaneous interactions. However, Brazilian Portuguese (BP) presents a clear distinction between natural oral speech grammar and formal written register grammar. Schooling is more conservative and requests a more formal use of the language, with characteristics that are sometimes in conflict with oral speech. This distance between oral speech and formal register may be addressed in generative terms, considering the notions of internalized grammar and marked periphery (Chomsky, 1981; Kato, 2005). The natural growth of a grammar during the earliest years of language acquisition constitutes a core grammar, which is available to all native speakers of any language, enabling them to produce and comprehend sentences in that language. A marked periphery may be added to this core grammar and may be expanded through the next years of life of any speaker, through exposition to formal varieties of language, loans, schooling, etc. 
In a context of variation such as that characterizing $\mathrm{BP}$, it is of great interest to investigate how linguistic variation is processed in order to provide relevant information about the factors interacting with variation, so that the aim of providing access to the formal register of the language may be properly carried out by school. In this paper, this tension between natural grammar and formal registers of $\mathrm{BP}$ is considered from both a perspective of language acquisition in the earliest years and for the acquisition of a marked periphery in the late years of schooling. For young children, the tension between marked and unmarked plural forms is addressed. For older people, the use of anaphoric forms in object position is investigated for Youth and Adult Education students.

This paper is organized as follows. The next section presents the issue of the relationship between linguistic knowledge and literacy in the sense discussed by Kato (2005). Section 3 presents a brief overview related to the processing of linguistic variation. Sections 4 and 5 present the two specific phenomena here investigated, namely, variable verbal agreement and anaphoric direct object in BP. The last section brings some final remarks.

\section{Literacy and linguistic knowledge: core grammar or marked periphery?}

Chomsky (1981; 1986) introduced the notions of 'E-Language' and 'I-Language.' The initials ' $\mathrm{E}$ ' and 'I' refer to the main properties associated to each concept: E-Language is defined as 'extensional' and 'external' while I-Language is characterized as 'individual', 'internal' and 'intensional'. According to Chomsky, languages cannot be defined or individuated extensionally or mindexternally, and therefore the I-language view would be the only scientifically relevant approach for a theory of language (Scholz, Pelletier \& Pullum, 2016).

In the I-language view mentioned above, language is 'individual', that is, it is a property of individual human beings. This approach introduces a contrast between the idiolect of a single individual, and a dialect or language of a group (that could be defined by its geographical, social, historical, or political characteristics). Thus, I-languages are properties of the minds of individuals who know them (Scholz, Pelletier \& Pullum, 2016). I-language is also defined as 'internal' in the sense that it refers to a state of the mind/brain. Finally, I-languages are 'intensional' in contrast with 'extensional' in a logic and semantic sense: in a given world, the extension of a predicate like 'small' is the set of all small objects, whereas the intension is a function that picks out all the small objects contained in the same given world. Considering this distinction, a language can be identified with the set of its expressions or utterances (extensional view) but it can also be identified intensionally by means of a formal specification of some kind, a 'grammar' in the generative framework.

Kato (2005) highlights that the concept of I-Language does not distinguish the linguistic knowledge of a child starting school and that of a person who has undergone the whole process of literacy. Considering specifically BP, Kato takes 
into account that the grammar of spoken language is not exactly the same of the written grammar. In this sense, Kato claims that written register learning in BP is similar to an L2 acquisition process as speakers of BP learn some grammatical rules specific to the written language that are no longer used on spoken language, for example, the use of null subjects and clitic pronouns in complement positions.

For Kato (2005) the linguistic knowledge of a contemporary literate speaker of BP is not the same as that available in ancient grammars. It is neither the same of the linguistic knowledge of EP (European Portuguese) speakers. Based on diachronic data, it was verified that the schooling process could simulate Portuguese ancient grammar only partially. Besides, the comparison of translations from Brazilian texts to European Portuguese shows that there is no linguistic homogeneity between them (Kato \& Raposo, 2001). In sum, a literate speaker of BP might have a different linguistic knowledge when compared to herself/himself before the process of schooling and, of course, when compared to an ancient BP speaker or to a contemporary EP speaker.

Chomsky $(1981 ; 1986)$ proposes the concepts of I-Language, core grammar and marked periphery (or peripheral grammar) to analyze the internal linguistic knowledge of a speaker of a given natural language. In addition to the previously mentioned characteristics, I-Language is defined by properties of two types: i) those which are invariable and which define natural languages, but do not distinguish them - the Principles; and ii) those defined by positive $(+)$ or negative (-) values and responsible for specificities and variation between languages -the Parameters.

For Chomsky, when all parameters are defined by their + or - values, a core grammar is obtained - that is, the set of grammatical properties naturally represented in the mind of an individual. However, I-language is composed not only by the core grammar, but also by a peripheral grammar. In other words, outside of core grammar is the set of peripheral or marked properties of the language. These "peripheral" properties might include changing processes, innovations on the language and word loans. Idiosyncratic features of the language can also be found on peripheral grammar.

In this sense, Kato claims that the process of literacy can provide different values from those marked on core grammar. Stylistic rules, for instance, are understood as part of marked periphery. According to Kato (2005), a literate speaker has a bigger peripheral grammar than a non-literate one. So, the peripheral grammar is responsible for enlarging the I-language with a "second" grammar acquired/learning based on the input of schooling process and the immersion on written texts.

\section{Linguistic variation processing}

Although studies about linguistic variation exhibit an interest about how language structures function cognitively, the way social information is represented in mind does not necessarily constitute the focus of this approach. 
The study of the cognitive and perceptual dimensions of linguistic variation has been progressively highlighted in the literature on linguistic processing and is currently a relevant research topic (Campbell-Kibler 2009, 2010; Labov et al., 2011; Squires, 2013, 2014, among others). Squires (2013) points out that recent studies in speech perception report that linguistic perception is influenced by social information just as social perception is influenced by linguistic cues.

According to Campbell-Kibler (2010), the social cognition model implicit in most of the studies on variation processing postulates that complex social reasoning is conscious and deliberative - that is, dependent on a "sociolinguistic monitor" -and contrasts with fast and automatic linguistic behaviors related to the use of the vernacular. Vernacular is the linguistic repertory acquired early and spontaneously and constitutes the socially "default" variety used by speakers. Labov (1972) claimed that the use of the vernacular would involve both "social" (or sociolinguistic) processes and more automatic linguistic processing. The use of the vernacular variety would, however, be also "controlled" by a sociolinguistic monitor which would involve more conscious processes. This monitor seems to be responsible for more or less formal uses in specific contexts or social situations. A key feature of this approach is the idea that in order to gather the linguistic resources necessary to achieve a particular social goal, speakers must consciously monitor their speech.

Speaker's goals can involve much more than just the search or maintenance of social status or prestige. Speakers may exhibit linguistic behaviors that support complex and intentional identity projects. The existence of more complex social objectives suggests a fast sociolinguistic processing, which allows, for instance, relating small pieces of linguistic information (such as phonetic variants) and agentive social choices (such as self-presentations or attempts to demarcate solidarity or distance).

In this context, a relevant question is how conscious our sociolinguistic reasoning is. To answer this point it is important: (i) to investigate the skills of speakers and listeners to adapt their linguistic processing to social objectives in certain situations; but also (ii) to assess the inability that individuals present at times to make such kind of adaptations.

Evidence found in the literature on the functioning of social cognition focuses on three main areas: impression formation, social goals obtaining and groupbased stereotypes. The sociolinguistic variation processing in a psycholinguistic approach per se is relatively little researched topic to date. Squires $(2013,2014)$ investigates the sociolinguistic perception of morphosyntactic variation (English subject-verb agreement constructions) by means of sociolinguistic priming experiments and psycholinguistic experiments (self-paced reading tests). The results of the sociolinguistic priming experiments suggest that: 
the perceptual relationship between linguistic and social knowledge may be one of only limited bidirectionality. (Squires, 2013: 200).

Regarding psycholinguistic experiments, Squires (2014) reports that when the participants were considered as a uniform group - independent of the social variables investigated, such as socioeconomic status, race/ethnicity, and sex nonstandard (s/he don't...) and "uncommon"agreement (they doesn't...) led to longer reading times than standard agreement (s/he doesn't - they don't). Similar results have been reported for BP when standard and non-standard nominal and verbal agreement processingwere compared (Henrique, 2015; Azalim, 2015; Marcilese et al, 2015, 2017; Azalim et al, 2018). According to these studies, non-standard variety processing registers significantly longer reaction times in self-paced listening, self-paced reading and elicited production tasks, both for children and adults.

In addition, studies such as Hanuliková et al. (2012) also provide evidence consistent with the idea that sentence processing is, in some way, sensitive to non-linguistic or social patterns. In this case, ERP records were compared against sentences containing gender agreement errors spoken by a native or by a nonnative speaker.The results indicate that gender violations in native discourse result in a $\mathrm{P} 600$ effect, but when the same violations were produced by non-native speakers with a foreign accent, no P600 effect was observed.

According to Squires (2014), the few studies that approach the processing of variation indicate that:

a- Processing is gradiently sensitive to degrees of experience with variants, and is more difficult for variants outside of one's own baseline;

b- Processing depends on one's expectations about which variants are likely; and

c- Both linguistic and nonlinguistic information can affect expectations. (SQUIRES, 2014:180).

Considering that the sociolinguistic repertoire of speakers is amplified by the exposure to the several varieties available in a given linguistic community, the role of mother-tongue education is crucial in relation to the possibility of providing the contact with standard variety. In the following sections, we will discuss two specific BP phenomena in which the sociolinguistic dimension and the role of the school are particularly evident: the variable verbal agreement and the expression of anaphoric direct object.

\section{Variable verbal agreement in $\mathrm{BP}^{2}$}

Brazilian Portuguese exhibits variable number agreement in the nominal phrase and in subject and verb relationship (Scherre; Naro, 2006; Naro; Scherre, 2007). On the nominal domain, all the relevant elements can be marked for plural or, alternatively, plural information can appear just in the determiner (1). On the 
verbal domain, both the subject and the verb can receive plural marks or just the subject (2). Thus, two main agreement rules can be identified in BP: redundant and non-redundant morphological marking.

(1) Umas-PL meninas-PLbonitas-PLversus Umas-PLmenina- $\emptyset$-sING bonita$\varnothing$-SING

Some beautiful girls.

(2) Elas-PLusam-PLchapéuversusElas-PLusa-Ø-sINGchapéu.

They wear hat.

Variable number agreement patterns in BP have been extensively investigated in Sociolinguistics literature, with the focus on adult production data. Studies have pointed out social and linguistic factors that may (dis)favor the occurrence of non-redundant morphological marking, such as age range, schooling and social class as social factors, and phonic salience and distance between the subject and the verb, among other linguistic factors (Viera, 1994; Costa, 1994; Scherre \& Naro; 1998, 1997; Silva, 2005; Santos, 2010).

Concerning children data, few studies have looked into this topic. Ferrari Neto and colleagues (Ferrari Neto, 2008; Corrêa, Augusto\& Ferrari Neto, 2005) investigated BPtwo-year-old children's comprehension of plural information in nominal agreement (between determiner and noun in DP) in sentences with redundant (3) or non-redundant morphological markings (4). Ungrammatical number agreement marking sentences were also presented as control condition (5):

(3) Ache as bolas pro Dedé.

Find the-PL balls- $P L$ for Dedé

Show the balls to Dedé

(4) Mostre as estrela pro Dedé.

Show the-PL ball- $\varnothing$-SING for Dedé

Show the balls to Dedé

(5) *Ache o gatos pro Dedé.

Find the- $\emptyset$-SING balls-PL for Dedé

*Show these ball to Dedé

Children performed similarly in both experimental conditions, showing a great number of target responses for redundant and non-redundant agreement sentences. Contrastively, they showed poor performance in the control condition. These results suggest that at age of two years, BP-speaking children are able to deal with two nominal agreement rules in order to identify number information on the DP.

Castro (2007) and Castro e Ferrari Neto (2007) point out that two-yearold children acquiring EP perform differently when exposed to these same linguistic stimuli. Although Portuguese children identified plural information on both conditions (redundant and non-redundant agreement), extracting 
number information from the determiner, a better performance was verified on redundant condition - the variety largely observed in EP. On the other hand, Brazilian children had similar performance for both conditions, presumably, due to the variation children are exposed to, as mentioned above.

Concerning language production, Jakubów e Corrêa (2018) verified to what extent five-year-old children from different social classes (public or private school) would show preference for one or another pattern of number agreement (redundant or non-redundant agreement patterns). Four conditions were assessed on an elicited production task:

(6) Os cachorros encontraram o leão. (DP red/V red)

The-PLdogs-PL found-PL the lion

(7) Os cachorros encontrou o leão. (DP red/V non-red)

The- $P L$ dogs- $P L$ found- $\varnothing$-SING the lion.

(8) Os cachorro encontraram o leão. (DP non-red/V red)

The-PL dog- $\varnothing$-SING found-PL the lion.

(9) Os cachorro encontrou o leão. (DP non-red/V non-red)

The-PL dog- $\emptyset$-SING found- $\varnothing$-SING the lion.

The dogs found the lion.

Results show that the group from private school produced more sentences in the standard form, changing non-redundant forms to redundant ones, differently from the other group (public school) that did not show preference for neither condition as they produced a greater number of sentences without redundant marks. The authors claim that children at the age range assessed not have begun the literacy learning process and therefore their performance would reflect the natural internalized grammar. In this sense, it would be expected that formal schooling process increases the production of redundant agreement forms, as shown by sociolinguistic studies with adults from different levels of formal education.

\subsection{Verbal inflection comprehension by schooling BP- learningchildren}

Studies in several languages, which - differently from BP - exhibit consistent number inflection patterns (English, Czech and also Romance languages such as Spanish and French), point out that, although children produce number inflection by the age of three, they have difficulty with comprehension tasks until the age of six (Johnson, de Villiers\& Seymor, 2005; Pérez-Leroux, 2005; Legendre et al., 2010; Bláhová \& Smolik, 2014). Taking this into account, it is worthy to investigate to which extent BP-speaking children would have extra difficulty in a verbal agreement comprehension task.

Molina (2018) investigated the perception of the $3^{\text {rd }}$ person plural verbal inflection and the comprehension of the concept of plurality conveyed by this morpheme by 5 and 6-year-old Brazilian children. As in the Spanish study 
(Pérez-Leroux, 2005), Molina compared sentences wherein number information (singular and plural forms) was presented only on the verb (null subject condition) with conditions wherein number information was both on the subject and the verb (lexical subject condition). The hypothesis assumed was that redundant number information (both on the subject and the verb) would facilitate the identification of number information, considering that it is more perceptually salient in this condition and that previous results indicate that children perform better in lexical subject sentence conditions compared to null subject ones (PérezLeroux, 2005; Martins, 2007).

A difference in participants' performance due to age range would indicate a developmental path in verbal markings comprehension and the influence of schooling process as the standard variation of the language is reinforced at school.

Thus, the research questions under investigation were:

- To what extent do children in the assessed age range identify number information when they are exposed to null subject sentences mapping the sentence they hear with the concept of numerosity (singular as one element and plural as more than one element)?

- Does redundant information on lexical subject condition facilitate the task in some way considering that BP presents variable verbal agreement?

- Does age range/level of formal education influence Brazilian children's performance?

- Are plural sentences easier/faster interpreted than singular sentences?

Four experimental conditions were assessed considering the variables number (singular vs. plural) and type of subject (null vs. lexical):

- Null subject plural condition:

e.g., Tocaramviolão.

(They) played-PL the guitar.

- Null subject singular condition:

e.g., Tocouviolão.

(He/She) played-sING the guitar.

- Lexical subject plural condition:

e.g., Ascrianças tocaramviolão.

The- $P L$ children- $P L$ played-PL the guitar.

- Lexical subject singular condition:

e.g., A criança tocou violão.

The-SING child-SING played-SING the guitar. 
A picture selection task was developed as a computer game in which the participant hears a sentence through headphones and chooses one of the two images that better represents it. All sentences were previously recorded and edited on Praat software. The experiment was presented on Psyscope. As soon as the linguistic stimulus was finished, visual stimuli (two simultaneous images) were presented on the computer screen. Both images displayed two characters: in one image, only one character performs the verbal action while in the other, two characters perform the verbal action, as the example below in Figure 3 (e.g., Tocaram violão - '(They) played the guitar'):

Figure 1: An example of a visual stimulus presented in the task.
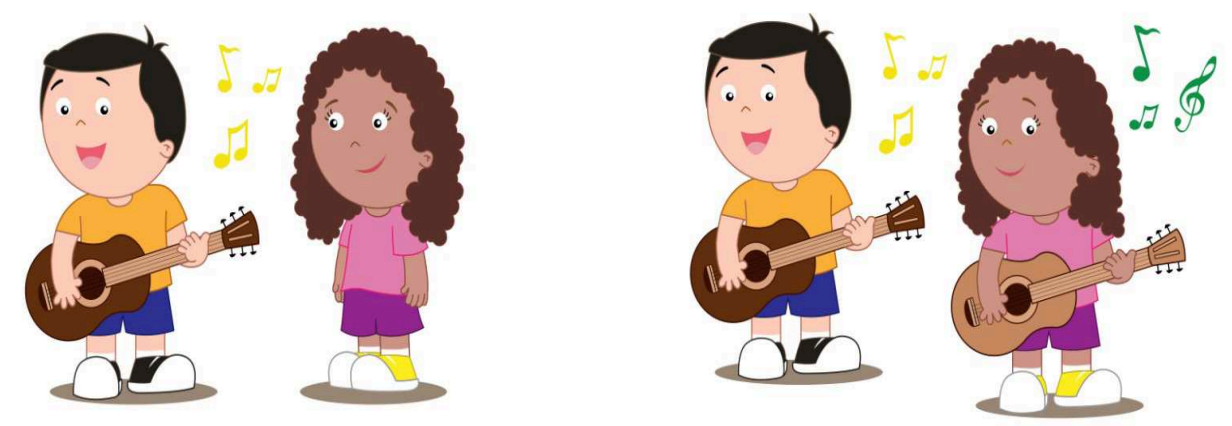

The participant should press one of the three computer keys indicated on the keyboard: one indicating the image on the left, one indicating the image on the right or a central key that should be pressed in case of doubt (if no image is considered a good choice to represent the sentence heard). When a computer key is chosen, the software registers how long it took between the end of the linguistic stimuli and the time the decision was made. Mean reaction time and mean of target responses were taken as dependent variables.

32 monolingual Brazilian children participated in the experiment separated into two groups based on level of formal education - 16 six-year-old school children (first grade of elementary school) and 16 ten-year-old school children (fourth grade of elementary school). 20 adults with high level of formal education composed a control group.

Mean accuracy for each experimental condition for the different groups is presented in the graphic below: 
Figure 2: Mean accuracy for each experimental condition by each group (Max Score $=3$ ).

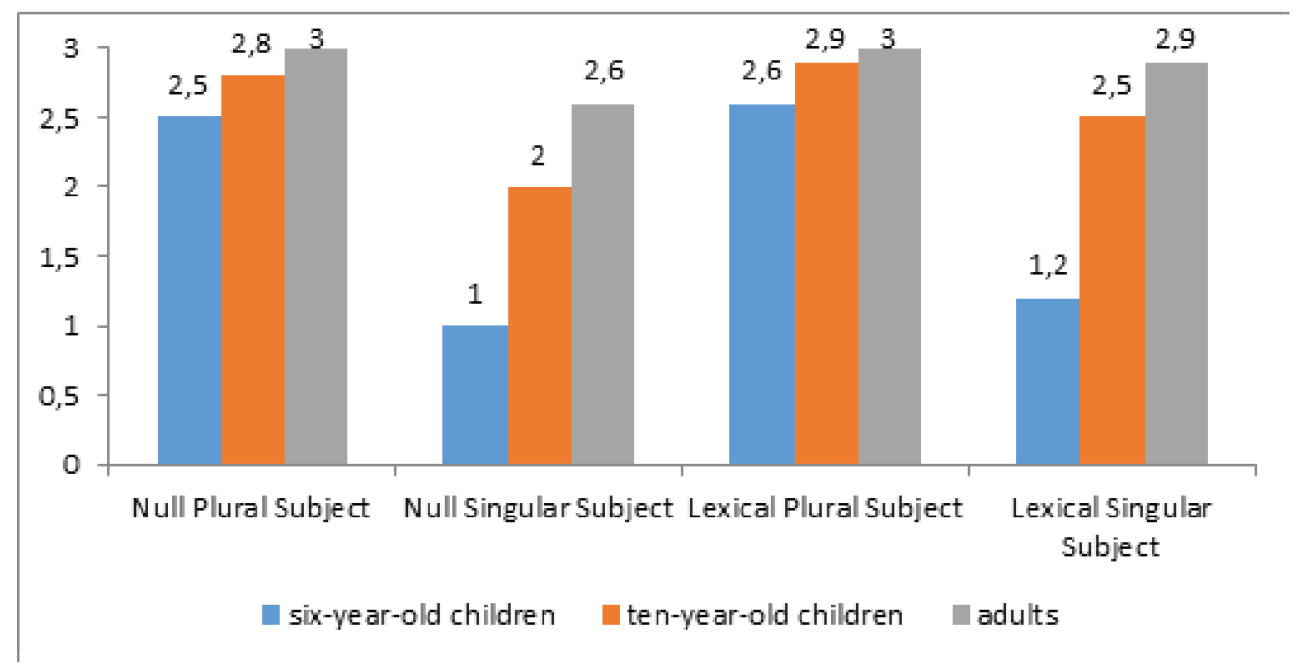

Data were submitted to a non-parametric test. The statistical analysis revealed a significant difference for mean accuracy on six-year-old group $\left(X^{2}(3)=20,207\right.$, $\mathrm{p}=.000)$. The following pairs revealed a statistic difference when the Wilcoxon test was applied: lexical plural subject $v s$. lexical singular subject $\left(Z=-2,791^{\mathrm{a}}, \mathrm{p}=.005\right)$; Lexical plural subject $v s$. Null singular subject $\left(\mathrm{Z}=-3,245^{\mathrm{a}}, \mathrm{p}=.001\right)$; Null singular subject $v s$.Null plural subject $\left(\mathrm{Z}=-2,803^{\mathrm{a}}, \mathrm{p}=.005\right)$. In the ten-year-old group the statistical analysis also revealed a significant difference for mean accuracy $\left(X^{2}(3)=15,481, p=.001\right)$. The following pairs were statistically different: Lexical plural subject $v s$. Null singular Subject $\left(\mathrm{Z}=-2,739^{\mathrm{a}}, \mathrm{p}=.006\right)$; Null plural subject vs. Null singular subject $\left(\mathrm{Z}=-2,762^{\mathrm{a}}, \mathrm{p}=.006\right)$. The adults' data also showed a significant difference when a general comparison was considered $\left(X^{2}(3)=15,529\right.$, $\mathrm{p}=.001)$. Lexical plural subject vs. Null singular subject $\left(\mathrm{Z}=-2,828^{\mathrm{a}}, \mathrm{p}=.005\right)$ and Null plural subject $v$ s. Null singular subject $\left(Z=-2,828^{\mathrm{a}}, \mathrm{p}=.005\right)$ revealed a significant statistic difference.

Altogether, considering the dependent variable mean of target responses, the experimental results suggest that when exposed to number marking on the verb, even in cases of null subject, Brazilian children identify this number information and map the verbal form to "plural" images. Moreover, an age developmental trait was verified as ten-year-old children had a more similar performance to adults than the one verified in the six-year-old group.

Reaction time was also registered for each group: 
Figure 3: Mean reaction time for each experimental condition by each group.

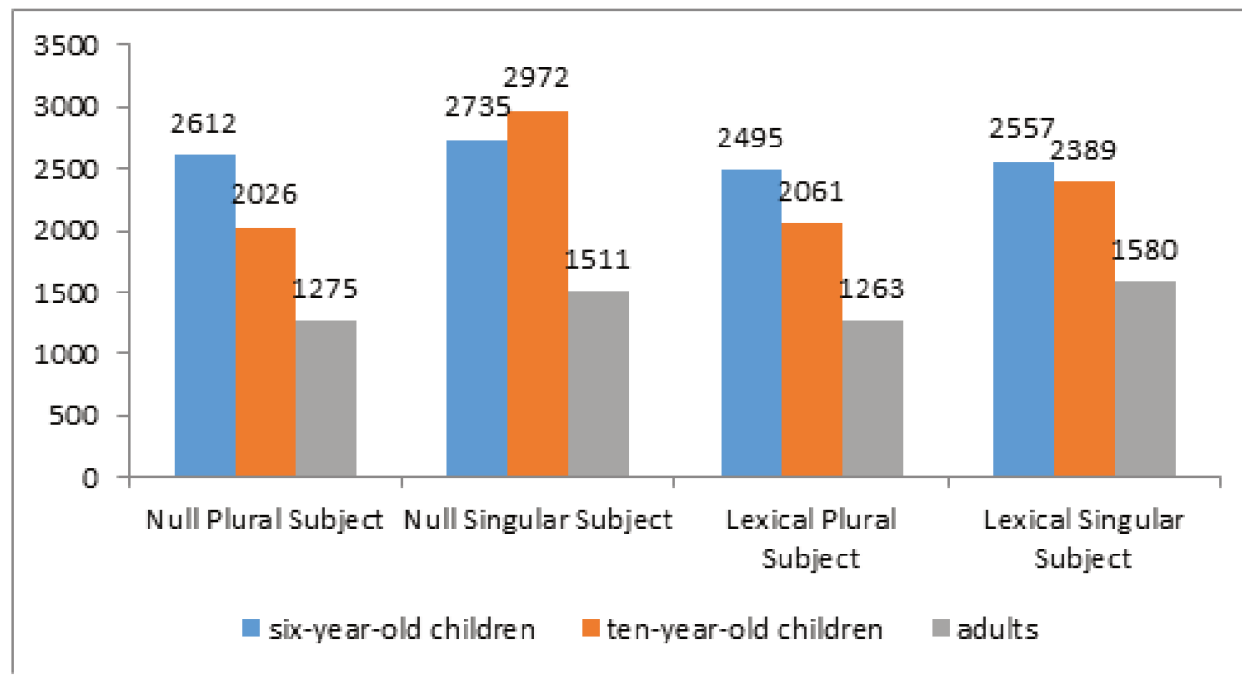

The data were analyzed by ANOVA. The reaction time in the six-year-old group revealed no statistically significant effect. For each experimental condition, participants had similar reaction times to make their decision. Differently, in the ten-year-old group, there was a significant effect of number $(\mathrm{F}(1,15)=30.4$, $\mathrm{p}<.00006$ ): children took longer times to choose one of the two images on singular conditions. The same effect was found for the adult group $(\mathrm{F}(1,19)=$ 17.6, $\mathrm{p}<.0004)$.

Figure 4: Mean reaction time as a function of number effect.

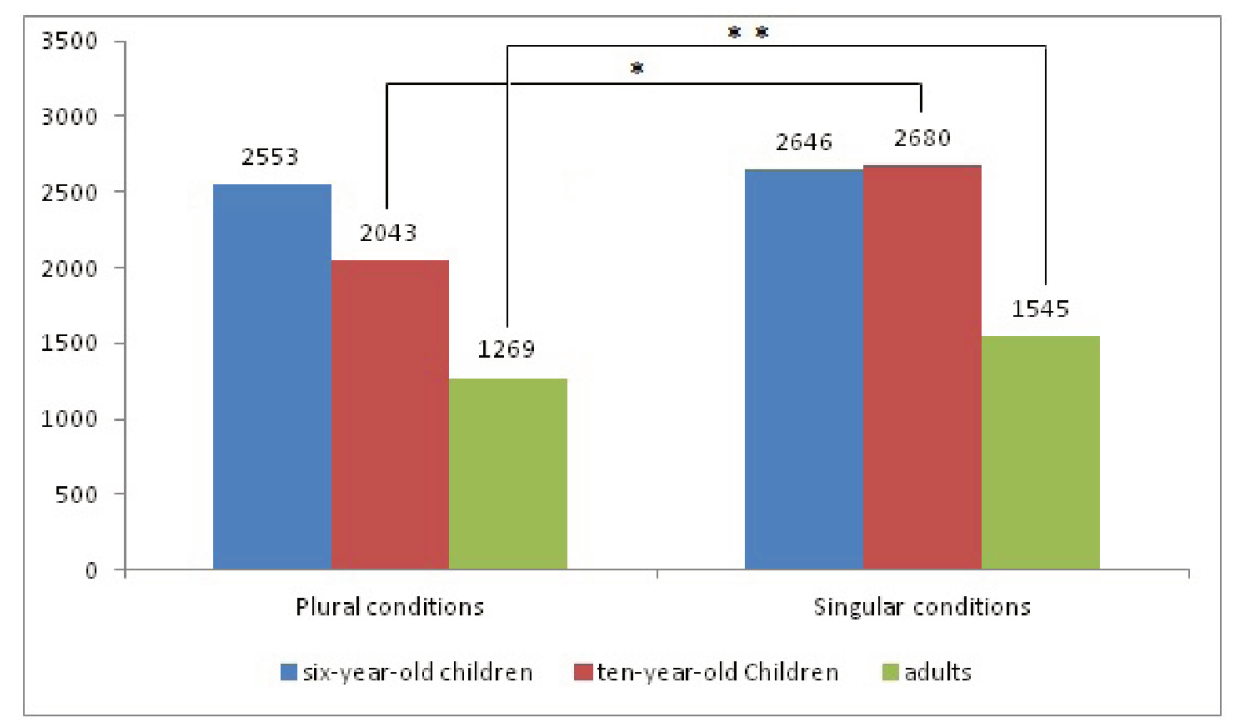

Although BP presents variable verb agreement patterns, the experimental results suggest that when exposed to number marking on the verb, even in cases of null subject, Brazilian children identify this number information and map the verbal form to "plural" images. On the other hand, redundant information on the DP subject and the verb seems to facilitate the task, as more target responses 
were obtained on the lexical subject condition than the null subject condition (specially with singular sentences). Besides, the formal schooling process seems to be a relevant extra linguistic factor that influences task performance.

\section{Anaphoric Direct Object in BP}

As mentioned previously, BP presents very particular features that differentiate oral from written registers. The use of anaphoric direct object is a clear example. Four variants have been identified in the language: accusative clitics (i), nominal phrases (ii), null objects (iii), and strong lexical pronouns (iv) (examples from Duarte, 1989):

(10) Ele veio do Rio só para me ver. Então eu fui ao aeroporto buscá-lo.

He came from Rio to visit me. So I went to the airport to pick him up.

(11) Ele vai ver a Dondinha e o pai da Dondinha manda a Dondinha entrar, ele pega um facão...

He visits Dondinha and her father tell Dondinha to come in, he grabs a knife...

(12) Ontem ele quis matar _ a empregada é que salvou _. Ele estava prontinho pra dar o tiro, quando a Mina chegou lá, passou um pito nele e convenceu _ que ele não devia matar

Yesterday he wanted to kill (him), his maid saved (him). He was about to fire when Mina arrived, discussed with him and convinced (him) not to kill (him).

(13) Eu amo o seu pai e vou fazer ele feliz.

I love your father and will make he(him) happy

The use of clitics (10) is absent from informal oral speech. It may be argued that it is not part of the internalized grammar of most children acquiring BP. However, if children are in contact with book storytelling, or the reading of the Bible, they may encounter some examples of clitic use. Apart from that, it is quite rare in informal oral production, which constitutes most of the type of interaction that young children experience. So, for many speakers, contact with clitics will be postponed until school begins. In school, children will face an attempt to present grammatical rules for the use of the language quite different from those prevailing in speech, and start to notice the expressive distance between the grammar of speech and that of writing. It is then the school environment (or exposure to more formal data of the language) that will be responsible for enlarging the marked periphery of BP speakers. Since the attempt to grasp such rules will be postponed to older age, Kato (2005) argues that the process of learning written Portuguese by a Brazilian individual would be similar to a process of learning a second language.

Duarte (1989) shows, for adult oral production data, that the most commonly used variant for the expression of an anaphoric element in direct object position 
is the null object (62.6\%); there is very little use of clitics (4.9\%), and some use of nominal phrases (17.1\%) and strong pronouns (15.4\%). It is interesting to point out that the choice of the variant seems to be influenced by the animacy status of the antecedent; that is, the choice of the null object is favored by the [- animated] feature of the antecedent (as well as nominal phrases), while clitics and strong lexical pronouns are associated with [+ animated] antecedents. It is worth mentioning that both strong pronouns and null objects are not endorsed by traditional grammars. Actually, Duarte's study shows that the more educated an individual is the more use of clitics he/she does. So oral production is affected by schooling in so far as what school presents as prestigious/the relevant written form is incorporated in the oral production of educated people.

In particular, the use of strong pronouns is stigmatized in general, being associated with low levels of formal education and it is not used in EP. Traditional grammars rarely admit structural differences between Portuguese varieties, favoring the European one as the legitimate norm of the language. Another characteristic that pulls apart BP from EP is the positioning of clitics. BP prefers proclitic position (14); EP privileges enclitic positioning (15). BP has also lost clitic climbing - the long movement of clitics in verbal complexes (Pagotto 1992; Perini 2000), that is, (16), which is common in EP, is almost absent even from written BP:

(14) Maria me viu no cinema.

(15) Maria viu-me no cinema.

Maria saw me at the cinema.

(16) Maria não me pode ver.

Maria cannot see me.

The distinction between oral and written registers and the role school plays in it is discussed by Corrêa (1991), based on a comparison between oral and written reports provided by illiterate people (only oral production, in this case), school students (1st to 8th grade), and graduated speakers. Students from the initial grades and illiterate individuals show great similarity in the use of anaphoric variants in direct object position in oral speech: no use of clitics, but fair use of null objects (around 30\%) and strong pronouns (around 10\%). For graduated speakers, strong pronouns are almost absent $(1,3 \%)$, there is a considerable drop of null objects $(12,4 \%)$ and the use of clitics is attested (2\%). Actually, occurrences of clitics are only attested after $5^{\text {th }}$ grade. Written data, on its turn, shows a different picture: a considerable decrease of null objects and strong pronouns, as well as an increase in the use of clitics, in general, is observed. Strong pronouns are absent from graduated speakers' performance and its percentage of use is never higher than $4,5 \%$ in written texts for any grade. Clitics appear in texts from the third grade and reach $18 \%$ of use for graduated speakers. Therefore, strong pronouns seem to be avoided in written texts while the clitics are more expressively present in this modality. Corrêa (1991) observes, though, that there is some "incorrect 
use" of clitics, which demonstrates an attempt to use this variant, which begins to be part of the child's vocabulary, but it is not mastered yet as prescribed by the rules of written manuals.

Pires (2015) also observes the use of anaphoric elements in direct object position in written data for second elementary education (7th, 8th and 9th years), high school (1st, 2nd and 3rd years) and graduation (initial and complete graduation). A developmental trait is also observed in terms of less use of strong pronouns and null objects and more use of clitics as formal education advances.

Table 1: Type of anaphoric variant and level of formal education

\begin{tabular}{llllll}
\hline Level of education & $\begin{array}{l}\text { Null ob- } \\
\text { ject }\end{array}$ & NP & $\begin{array}{l}\text { Lexical } \\
\text { pronoun }\end{array}$ & Clitic & Total \\
\hline Second Elementary & 106 & 25 & 38 & 120 & 289 \\
School & $36,7 \%$ & $8,7 \%$ & $13,1 \%$ & $41,5 \%$ & \\
High School & 68 & 21 & 8 & 189 & 286 \\
& $23,8 \%$ & $7,4 \%$ & $2,8 \%$ & $66,1 \%$ & \\
Graduation & 51 & 19 & 19 & 190 & 287 \\
& $17,8 \%$ & $6,6 \%$ & $6,6 \%$ & $66,2 \%$ & \\
Total & 225 & 73 & 65 & 499 & 862 \\
& $26,1 \%$ & $8,5 \%$ & $7,6 \%$ & $57,9 \%$ & \\
\hline
\end{tabular}

Reprinted from: Pires, 2015.

A subtle developmental trait in the correct positioning of the clitics in accordance to the formal written rules traditional grammar endorses is also observed:

Table 2: Adequate and inadequate positioning of clitics in Pires (2015)

\begin{tabular}{llllll}
\hline Clitic positioning & $\begin{array}{l}\text { Adequate } \\
\text { proclisis }\end{array}$ & $\begin{array}{l}\text { Adequate } \\
\text { enclisis }\end{array}$ & $\begin{array}{l}\text { Inadequate } \\
\text { proclisis }\end{array}$ & $\begin{array}{l}\text { Inadequate } \\
\text { enclisis }\end{array}$ & Total \\
\hline Second Elementary & 45 & 61 & 12 & 2 & 120 \\
School & $37,5 \%$ & $50,8 \%$ & $10,0 \%$ & $1,7 \%$ & \\
High School & 72 & 103 & 8 & 6 & 189 \\
& $38,1 \%$ & $54,5 \%$ & $4,2 \%$ & $3,2 \%$ & \\
Graduation & 79 & 107 & 2 & 2 & 190 \\
& $41,6 \%$ & $56,3 \%$ & $1,1 \%$ & $1,1 \%$ & \\
\hline
\end{tabular}

Reprinted from: Pires, 2015.

\subsection{Anaphoric direct object production by regular and EJA students}

Armando (2018) is also a contribution to the topic, investigating the school segment of Youth and Adults (EJA in Brazil). ${ }^{3}$ These students may show particular characteristics, since they may be away from school for significantly long periods. 
Also, school content they are exposed to is more condensed and presented faster, with fewer opportunities to practice. Does this population rapidly grasp the distinctions between oral and written aspects of language use? Is school capable of recovering the use and positioning of clitics? How much is this process similar to a foreign language learning one, in so far as a conscious effort is needed?

An elicited production task experiment was developed during which it was necessary to complete 40 gaps in written narrative-descriptive texts. The test was applied to EJA students and a control group from standard school in similar grades. The kind of anaphoric element used, the type of antecedent (in terms of animacy) and, if clitics were used, their positioning was observed. Gaps in the texts offered a simple verb or a verbal complex to be used (expectedly with an anaphoric element) by the student in order to complete the sentence. Thus, the independent variables were: Type of Verb (Simple Affirmative, Simple Negative, Auxiliary Complex, Modal Complex, ECM), Semantic type of the antecedent (animate, inanimate), Grade (9th grade fundamental, 3rd grade high school) and Type of School (EJA, regular school). The dependent variables considered the type of anaphoric element used (clitic, strong lexical pronoun, nominal phrase, null object) and, if clitics were used, their positioning (before the main verb or auxiliary, between auxiliary and verb, after the main verb).

The following predictions were drawn, according to previous results in the literature (Duarte, 1989; Corrêa, 1991; Pires, 2015):

(a) low productivity of accusative clitics (CL) and a greater association of this category with the [+ animate] feature of the antecedent;

(b) high use of null objects (NO) and a more significant association with the [- animate] context;

(c) avoidance of strong lexical pronouns (LP), with greater use in complex sentences, particularly ECM-type of sentences;

(d) more difficulty with verbal complexes than simple verbs for sticking to the rules of written register grammar, particularly in relation to clitic positioning;

(e) clear difference between EJA students and the control group, given EJA's less constant contact with the school context and the exposure to rules of written register.

63 students ( 33 from the EJA: 17 from the 9th grade, 16 from the 3rd grade; and 30 students from the regular school as a control group: 13 from the 9th grade, 17 from the 3 rd grade) were tested. Armando (2018) provides percentages and the results of some binomial mixed effects logistic regression models. No great difference was obtained between EJA and regular school results. A similar distribution of variants could be attested (including N/A - non-response or no use of an anaphoric element). 
Table 3: Types of anaphoric variants - 9th grade

\begin{tabular}{lll}
\hline Variants & EJA & Control \\
\hline Clitic & $93(13,7 \%)$ & $71(13,7 \%)$ \\
Null Object & $438(64,4 \%)$ & $360(69,2 \%)$ \\
Lexical Pronoun & $12(1,8 \%)$ & $6(1,2 \%)$ \\
NP & $10(1,5 \%)$ & $2(0,4 \%)$ \\
N/A & $127(18,7 \%)$ & $81(15,6 \%)$ \\
TOTAL & $680(100.1 \%)$ & $520(100.1 \%)$
\end{tabular}

Reprinted from: Armando (2018).

Table 4: Types of anaphoric variants - 3rd grade

\begin{tabular}{lll}
\hline Variants & \multicolumn{1}{c}{ EJA } & Control \\
\hline Clitic & $206(32,1 \%)$ & $230(33,7 \%)$ \\
Null Object & $363(56,6 \%)$ & $377(55,3 \%)$ \\
Lexical Pronoun & $28(4,4 \%)$ & $2(0,3 \%)$ \\
NP & $0(0 \%)$ & $0(0 \%)$ \\
N/A & $44(6,9 \%)$ & $73(10,7 \%)$ \\
TOTAL & $641(100 \%)$ & $682(100 \%)$
\end{tabular}

Reprinted from: Armando (2018)

Statistical analysis reveals no difference in the use of variants between the students in the $9^{\text {th }}$ grade (clitics and strong pronouns $-\mathrm{p}<0.198$; clitics and null objects $-\mathrm{p}<0.914)$. There is however a difference in the comparison between $9^{\text {th }}$ and $3^{\text {rd }}$ grades, with less use of null objects and more use of clitics (for EJA $\mathrm{p}<0.0007$; for regular school $-\mathrm{p}<0.0005)$. The comparison between clitics and pronouns shows a difference between $9^{\text {th }}$ and $3^{\text {rd }}$ grades only for the regular school (for EJA $-\mathrm{p}<0.54$; for regular school $-\mathrm{p}<0.0004$ ). So EJA students seem to be more resistant to dropping the strong pronoun.

The association of the variants with the animacy status of the antecedent is confirmed: null objects are more used with [-animate] antecedents, while clitics and pronouns are more used with [+animate] antecedents. Clitics have 2,5 times more chance of having a [+animate] antecedent than a [-animate] antecedent. It is quite clear thus that features of the core grammar of the individuals are at stake.

In relation to the positioning of clitics, preference for proclisis is generalized for both grades in both kinds of school, for simple verbs, irrespective of attractors (see (17) and (18)). In verbal complexes, it can be noticed that enclisis is privileged ((19) and (20)); that is, clitic climbing (long movement of the clitic) is no longer attested, as predicted. The use of the medial position in verbal complexes marks a difference between grades and types of school: for the EJA group, the use of the medial position grows with level of education $(p<0.001)$. In the comparison between the $9^{\text {th }}$ grades, students from the regular school make more use of the medial position $(\mathrm{p}<0.001)$, and no difference to the $3^{\text {rd }}$ grade of the regular school is observed $(\mathrm{p}<0.140)$ (see $(21)$. 
(17) Então eu o procurei para entender aquele estilo de vida...(Eja9Part11) So I looked for him so that I could understand that way of life..

(18) Dona Fabiana não o amava nem um pouco. (Eja9Part8)

Dona Fabiana didn't love him at all.

(19) A mãe conseguiu matricula-lás no teatro... (Eja3Part34)

Their mother managed to enroll them in acting classes.

(20) ... ele decidiu comprar um cofre e iria enchelo todos os dias com .... (Eja9Part1)).

... he decide to buy a safe and would fill it everyday with...

(21) Na nossa cidade, adoraram acampar perto das árvores. O tio passava horas vendo-os balançar... (Contr9Part27)).

In our city, they loved to camp by the trees. Their uncle spent hours watching them rock.

Armando (2018) also reports some individual analysis of the performance of the students form EJA, regarding the greater or lesser use of clitics in detriment of null objects and lexical pronouns. Students were designated as in the initial state, if less than 5 clitics were used and there was a high number of null objects; intermediate state, with 7 to 14 clitics used; and advanced states, when over 15 clitics had been used. Not surprisingly, all students in the initial state level were 9th graders. The intermediate level was composed of students from the $9^{\text {th }}$ and the $3 \mathrm{rd}$ grades. Regarding the advanced level, all students (but one) were 3rd graders. It is also important noting that the advanced group was consisted of younger students (between 18 and 20 years of age) and most of the older students were in the initial state. Thus, it seems that not being away from school for longer periods is more effective for schooling to succeed in teaching the rules of written register.

Armando's investigation only focused on production, but the attempts the students in general make in order to use the clitic suggest that clitics are noticed in the input and probably correctly understood, although sometimes students are not quite sure how to use them. There is clear individual difference performance, suggesting that this kind of language knowledge is attained in a very similar way to second language learning. Interference from core grammar makes it clear in the expressive use of null objects as an attempt to avoid lexical pronouns; when clitics are used, there is preference for proclisis, regardless of attractors; there is an inconsistent use of clitics and also the use of hypercorrections, as some of the data below exemplify:

(22) Quanto à tia má, ele iria ajudalo, mas...(Eja3Part31)

As far as his mean aunt, she would help him, but...

(23) A mãe conseguiu matricula-lás no teatro...(Eja3Part34)

Their mother managed to enroll them in acting classes

(24) Então, resolveram colocar-las em um cursinho de idiomas...(Eja9Part10)

Then, she decided to enroll them in a foreign language course

(25) ... ela não só não o deixou ele beber o leite todo... (Eja3Part34) 


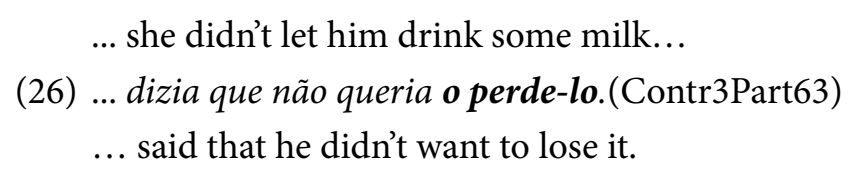

In example (22), orthographic mistakes are detected, and the clitic does not agree in gender with the antecedent. In (23), the clitic and not the verb receives the accent. In (24), the main verb did not lose the infinitive marking. In (25) and (26), there are double anaphoric elements being used, both the clitic and a strong pronoun in (25), and the clitic duplication in (26).

In sum, characteristics of written register seem to be recognized by students, but full mastery of this knowledge is dependent on exposure and practice, most of which is provided by schooling.

\section{Final remarks}

This paper has explored an intersection between three main topics: (i) sociolinguistic variation, (ii) variation acquisition and processing according to a psycholinguistic approach and (iii) mother-tongue teaching/learning when the two previous factors are taken into account.

As has been argued, nonstandard linguistic varieties coexist in society with a standardized variety, the so-called 'language of education'. In BP particularly, there are different degrees concerning the distance between standard forms and the variety acquired by children at home as a function of the dialect spoken primarily by their parents and the people in their close environment. Nevertheless, variation is pervasive and it could be said that Brazilian speakers are exposed to both nonstandard and standard varieties in higher or lower degrees. The issue of the extent to which a sociolinguistic monitor would allow speakers to "control", or be sensitive to, the use of one variety or the other in the context of such a highly variable environment is tentatively addressed here, focusing on experimental results. These regard the comprehension of verbal agreement by young children, and the use of anaphoric forms in direct object position, by late educated adults.

The results from the first study show that Brazilian children easily identify plural standard agreement. Singular agreement, however, seems to be more challenging, probably because of the fact that singular verbs could combine with plural subjects in the nonstandard variety. While plural forms are well recognized by children at the beginning of formal schooling and even after that (see Molina, 2018), singular forms are quite ambiguous. In addition, it was observed that the identification of the referents -as singular or plural- is harder for null subjects, that is, when the only source of relevant information is the verbal inflection. This result reinforces the idea that BP verbal morphology may not be informative enough, requiring that additional clues be considered by the speakers. In the context of high sociolinguistic variation that characterizes BP, formal schooling is crucial for the consolidation of the linguistic pattern for agreement comprehension registered by adults. 
The results from the second study show that there is no great difference between the performance of regular or EJA students in the use of anaphoric elements in direct object position or clitic collocation, suggesting that schooling plays an important role in taking students to try to master the rules of the standard dialect. This is also confirmed by the fact that students from EJA who have been away from school for shorter times are the ones who show greater mastery of those rules. The non-consistent use of standard dialect rules, though, suggests that this phenomenon, in particular, is subject to a learning process, which resembles second language learning. Although speakers identify the forms of the standard dialect, they use them erratically.

The investigations reported here indicate that speakers are aware of the coexistence of variable systems present in the language and are able to deal with the distinct forms for extracting the necessary information in terms of relevant values of features. It also showed that schooling plays an important role in making students more conscious of the rules of the standard dialect, that is, the prestigious one.

\section{Notes}

1. The original statement is in Yiddish, a language originated during the nineteenth century in Central Europe.

2. The research reported in this section is related to the Project "Internal and External Interfaces in the Acquisition and Adult Processing of L1 and L2: agreement and topic/focus in BP", financed by FAPEMIG (Process APQ-00988/15). The Human Research Ethics Committee of the UFJF has approved the project.

3. The term EJA refers to the elementary school of Youth and Adult Education and New EJA (NEJA), to high school. However, we will use the term EJA for both segments. In addition, in order to draw a comparison with the control group, we will use the term 9th grade for the IX phase of the EJA and 3rd grade for the Module IV of NEJA. This research has been approved by the Human Research Ethics Committee of UERJ (CAAE: 58131016.9.0000.5282).

\section{References}

ARMANDO, R. Q. Manifestação do Objeto Direto Anafórico em Esfera Escolar EJA: a gramática do letrado. Dissertação de Mestrado, Universidade do Estado do Rio de Janeiro, 2018.

AZALIM, C. Variação e processamento linguístico: Um estudo experimental sobre a concordância nominal variável no PB Dissertação de Mestrado, Universidade Federal de Juiz de Fora, 2016.

AZALIM, C.; MARCILESE, M.; NAME, M. C.; SCHER, L.; GONCALVES, L. Concordância nominal variável de número e saliência fônica: um estudo experimental. DELTA. Documentação de Estudos em Lingüística Teórica e Aplicada, v. 34, p. 513-545, 2018.

BLÁHOVÁ, V.; SMOLIK, F. Early Comprehension of Verb Number Morphemes in Czech: Evidence for a Pragmatic Account. BUCLD 38 Proceedings, 2014. http:// westernlinguistics.ca/Publications/CLA-ACL/Perez-Leroux.pdf.

CAMPBELL-KIBLER, K. The nature of sociolinguistic perception. Language Variation and Change, v. 21, p. 135-156, 2009. 
CAMPBELL-KIBLER, K. 2010. New directions in sociolinguistic cognition. University of Pennsylvania Working Papers in Linguistics, v. 15, p. 31-39, 2010.

CASTRO, A.;FERRARI NETO, J. Um estudo contrastivo do PE e do PB com relação à identificação de informação de número no DP. Letras de Hoje, v. 42, p.65-76, 2007.

CASTRO, A. O processamento da concordância de número interna ao DP por crianças de 2 anos falantes de português europeu. In: M. Lobo \& M.A. Coutinho (eds) XXII Encontro da Associação Portuguesa de Linguística; Textos Seleccionados. Lisboa: Colibri, p.211-221, 2007.

CHESHIRE, Jenny. Sociolinguistics and mother-tongue education. In: Ammon, U., Dittmar, N., Mattheier, K., and Trudgill, P. (eds.).Sociolinguistics: an introductory handbook of the science of language and society. 2nd. edition, Berlin: Mouton de Gruyter, pp. 2341-2350, 2005.

CHOMSKY, N. Lectures on government and binding Dordrecht: Foris, 1981.

CHOMSKY, N. Knowledge of language New York: Praeger, 1986.

CORRÊA, V.R. O objeto direto nulo no português do Brasil. Dissertação de Mestrado, UNICAMP, 1991.

CORRÊA, L. M. S.; AUGUSTO, M. R. A.; FERRARI-NETO, J.. The Early Processing of Number Agreement in the DP: Evidence from the Acquisition of Brazilian Portuguese In: 30th BUCLD, Boston: Cascadilha Press, 2005.V.2.

COSTA, M. A. As definições de sujeito e seus traços de caracterizadores. O traço de concordância. In: ENCONTRO NACIONAL SOBRE LÍNGUA FALADA E ENSINO, I., 1994, Maceió. Anais... Maceió: EDUFAL, 1994. p. 315-320.

DUARTE, M.E.L. Clíticos acusativo, pronome lexical e categoria vazia no português do Brasil. In: TARALLO, F. (org.). Fotografias sociolinguísticas. Campinas: UNICAMP, 1989, pp. 19-34.

FERRARI-NETO, J. Aquisição de Número Gramatical no Português Brasileiro: Processamento de Informação de Interface e Concordância. Tese de Doutorado. Departamento de Letras. Rio de Janeiro: PUC-Rio, 2008.

HANULÍKOVÁ, A.; VAN ALPHEN, P. M.; VAN GOCH, M. M.; WEBER, A. When One Person's Mistake Is Another's Standard Usage: The Effect of Foreign Accent on Syntactic Processing. Journal of Cognitive Neuroscience, v. 24, n.4, p. 878-887, 2012.

HENRIQUE, K. S. Variação linguística e processamento: investigando o papel da distância entre sujeito e verbo na realização da concordância verbal variável no PB. Dissertação de Mestrado, Universidade Federal de Juiz de Fora, 2015.

JAKUBÓW, A.P.S.P.; CORRÊA, L. M. S. A expressão morfofonológica da concordância de número variável em português brasileiro: uma proposta para a aquisição e a produção infantil. Revista da anpoll (ONLINE), v. 1, p. 47-67, 2018.

JOHNSON, V. E.; DE VILLIERS, J. G.; SEYMOR, H. N. Agreement without understanding? The case of third person singular/s/. First Language, v. 25, n. 3 , p.317-330, 2005.

KATO, M. A. A gramática do letrado: questões para a teoria gramatical. In: Marques, E. Koller,J. Teixeira; A. S.Lemos (orgs). Ciências da Linguagem: trinta anos de investigação e ensino. Braga, CEHUM (U. do Minho), p.131-145, 2005.

KATO, M.; RAPOSO, E. O objeto nulo definido no português europeu e no português brasileiro: convergências e divergências. Actas do XVI Encontro Nacional da APL, Lisboa: p. 673-685, 2001. 
LABOV, W. Sociolinguistic patterns. Philadelphia: University of Pennsylvania Press, 1972.

LABOV, W.; ASH, S.; RAVINDRANATH, M.; WELDON, T.; BARANOWSKI, M.; NAGY, N. Properties of the sociolinguistic monitor. Journal of Sociolinguistics, v.15, p. 431-463, 2011.

LEGENDRE, G.; BARRIÈRE, I.; GOYET, L.; NAZZI, T. Comprehension of Infrequent Subject-Verb Agreement Forms: Evidence From French-Learning Children. Child Development. v. 81, n. 6, p. 1859-1875, 2010.

MARCILESE, M.; HENRIQUE, K.S. ; AZALIM, C. ; NAME, M. C. Processamento da concordância variável no $\mathrm{PB}$ em uma perspectiva experimental. Linguística (Rio de Janeiro), v. 11, p. 118-134, 2015.

MARCILESE, M.; RODRIGUES, E. dos S. ; AUGUSTO, M. R. A. ; HENRIQUE, K.S. Efeitos de distância linear e marcação no processamento da concordância verbal variável no PB / Linear distance and markedness effects in variable subject-verb agreement processing in BP. Revista de Estudos da Linguagem, v. 25, p. 1291-1325, 2017.

MARTINS, L. S. O. O traço de pessoa na aquisição normal e deficitária do português brasileiro. 199f. Tese (Doutorado em Letras). Rio de Janeiro: PUC-Rio, 2007.

MILLER, K.; SCHMITT, C. Variable vs. Consistent Input: Comprehension of Plural Morphology and Verbal Agreement in Children. In: BRUCART, J. M.; GAVARRÓ, A.; SOLÀ, J. Merging Features: Computation, Interpretation and Acquisition. New York: Oxford University Press, 2009, pp. 123-137.

MILLER, K.; SCHMITT, C.Variable Input and the Acquisition of Plural Morphology. Language Acquisition, 19:3, p. 223-261, 2012.

MOLINA, D. S. L. Aquisição da linguagem e variação linguística: um estudo sobre a flexão verbal variável na aquisição do PB. Tese de Doutorado, Universidade Federal de Juiz de Fora, 2018.

NARO, A. J.; SCHERRE, M. M. P (org.). Origens do Português Brasileiro. São Paulo: Parábola Editorial, 2007.

PAGOTTO, E. A posição dos clíticos em português: um estudo diacrônico. Dissertação Mestrado em Linguística, UNICAMP, Campinas, 1992.

PÉREZ-LEROUX, A. T. Number problems in children. Proceedings of the 2005 annual conference of the Canadian Linguistics Association, p. 1-12, 2005.

PERINI, M. A. Gramática descritiva do português. 4. ed. São Paulo: Ática, 2000.

PIRES, L. Aquisição da escrita-padrão do português brasileiro em esfera escolar: um estudo transversal. 2015.260f. Tese (Doutorado em Linguística). Universidade de Brasília, Brasília 2015.

SANTOS, R. L. de A. A concordância verbal na fala de menores carentes que vivem em entidades filantrópicas de Maceió. 2010. Dissertação (Mestrado em Linguística) Faculdade de Letras, Universidade Federal de Alagoas, Maceió, 2010.

SCHERRE, M. M. P.; NARO, A. J. A concordância de número no português do Brasil: um caso típico de variaçăo inerente. In: HORA, D. da (Org.). Diversidade linguística no Brasil. Joăo Pessoa: Ideia, 1997. p. 93-114.

SCHERRE, M. M. P.; NARO, A. J. Sobre a concordância de número no português falado do Brasil. In: RUFFINO, G. (Org.). Dialettologia, geolinguistica, sociolinguística. Centro di Studi Filogici e Linguistici Sicilliani. Universitá di Palermo. Tubingen: Max Niemayer Verlag, 1998. p. 509-523. 
SCHERRE, M. M. P.; NARO, A. J. Mudança sem mudança: a concordância de número no português brasileiro. SCRIPTA, Belo Horizonte, v. 9, n. 18, 107-129, 2006.

SCHOLZ, B. C.; PELLETIER, F. J.; PULLUM, G. K., "Philosophy of Linguistics", The Stanford Encyclopedia of Philosophy, Edward N. Zalta (ed.), <https://plato. stanford.edu/archives/win2016/entries/linguistics/>.

SILVA, J.A.A. A concordância verbal de terceira pessoal do plural do Brasil: um panorama sociolinguístico de três comunidades no interior do Estado da Bahia. 2005. 323f. Tese (Doutorado), Universidade Federal da Baía, 2005.

SQUIRES, L. (2014). Social Differences in the Processing of Grammatical Variation. Selected Papers from NWAV 42, 20(2): 178-188.

SQUIRES, L. It don't go both ways: Limited bidirectionality in sociolinguistic perception. Journal of Sociolinguistics 17/2, 2013: 200-237.

VIEIRA, S. R. Aspectos da concordância verbal em dialetos populares. In: ENCONTRO NACIONAL SOBRE LÍNGUA FALADA E ENSINO, I., 1994, Maceió. Anais...Maceió: EDUFAL, 1994. p. 323-327.

Recebido em: 10/03/2019

Aceito em: 30/07/2019 